\title{
Thom Brooks and the 'Systematic' Reading of Hegel
}

\begin{abstract}
Allen Wood
Hegel was a systematic philosopher, who grounded his system on a speculative logic. But his greatest philosophical contributions lie in his reflections on human culture: ethics, social and political philosophy, aesthetics, religion and the philosophy of history. This fact poses a problem for anyone who accepts it and then attempts to provide a philosophical discussion of Hegel's thought with the aim of making it available to a later age.

There can be no doubt that any authentic treatment of Hegel's social and political philosophy must take account of Hegel's explicit intention to ground it in his logical system of thought-determinations. But if we simply take that intention at face value, we make our appropriation of Hegel hostage to his philosophical system and speculative logic, which now are at best outdated and, though they may themselves contain some insights of lasting philosophical value, are not of nearly as much philosophical interest as Hegel's thoughts about human culture, society and history. A Hegel whose ethical, social, historical and cultural insights could be appropriated only by those who accept his speculative logical system would be a Hegel few would ever read or learn from.

The other horn of the same dilemma is that those interpreters who are honest enough that they don't accept uncritically Hegel's own account of the structure of his philosophical accomplishments will inevitably be charged with doing violence to Hegel's thought, ignoring its true structure and unity. To quote a passage from Fred Beiser, which Thom Brooks uses to pillory all such Hegel scholarship: 'We make Hegel alive and relevant, a useful contributor to our concerns; but that is only because we put our own views into his mouth. What we learn from Hegel is then only what we have read into him' (Brooks 2007: 10, originally in Beiser 2005: 44). Whether this is a fair or accurate description of anyone's Hegel scholarship (I think it is the very reverse of fair or accurate as applied to mine), it is an accusation you invite as soon as you try to present Hegel to any audience that has not already bought uncritically into his speculative logic.

In his monograph Hegel's Political Philosophy: A Systematic Reading of the Philosophy of Right, Thom Brooks is apparently determined at all costs to avoid the pitfall described by Beiser. He criticises those, like myself —Frederick Neuhouser, Charles Taylor, Robert Pippin, Paul Franco, Dudley Knowles, Michael Hardimon and several others are also mentioned in this connection - for offering 'non-systematic' readings of Hegel (as though, by not making our appropriation of Hegel hostage to his speculative logic, our readings were condemned to be haphazard or chaotic). According to Brooks, by refusing
\end{abstract}

Bulletin of the Hegel Society of Great Britain 66 (2012) 16-22 (C) the author 
to accept unquestioningly Hegel's assurances that the merits of his political philosophy are completely dependent on those of his speculative logic, we 'non-systematic' readers commit ourselves to a portrayal of Hegel's political philosophy that is guaranteed a priori not to be 'accurate' (Brooks 2007: 9).

Brooks declares that 'non-systematic' readings of Hegel 'argue that we can properly comprehend writings, such as the Philosophy of Right, independently of [Hegel's] larger system' (p. 4). But does anyone really argue this? I would say not. I can speak with certainty only for myself, but what I argue is this: Hegel's social and political philosophy should be comprehended as part of his system. There was never the least thought of denying that. More generally, it is a sound exegetical principle that any part of any philosopher's thought always needs to be comprehended (though always critically, and sometimes skeptically) in the context of the whole. But the valuable insights contained in Hegel's ethical thought can be presented and defended largely independently of the system of speculative logic that Hegel believed were their foundation. One need not accept Hegel's speculative logic in order to appreciate what is valuable in his ethical thought. There is nothing in this approach that requires your presentation of Hegel to be 'inaccurate.'

Brooks of course himself admits (Brooks 2007: 7) that no reading of Hegel is selfdescribed as 'non-systematic'; and for my own part I would reject the label as itself not in the least an 'accurate' description of the scholarship (mine or that of others) to which Brooks applies it. In short, the only choices Brooks would seem to give us are: (a) to attempt a quixotic defense of Hegel's speculative logic and his entire system or (b) to dismiss and ignore Hegel's cultural, ethical and historical insights because they belong to a philosophical system that few nowadays can take seriously.

Hegel purists - those whom I described in Hegel's Ethical Thought (1990) as 'an isolated and dwindling tradition of incorrigible enthusiasts' (Wood 1990: 5) — may be willing or even eager to embrace option (a), but they can make this choice seem even minimally reasonable only if they lump all alternatives to it together invidiously under the variant of option (b) described by Beiser in the above quotation. That is, either we accept Hegel's thought as a single opaque monolith, defending all of it, or else we find parts of it defensible only because we have 'read our own views into Hegel,' which guarantees a priori that we must not have read him 'accurately'. But surely this is an utterly false dilemma. It is quite possible to take account of Hegel's systematic intentions in one's understanding of Hegel's ethics and political philosophy without committing oneself to the proposition that his accomplishments correspond to those intentions. As Hegel himself said, 'The truth of the intention is only the deed itself (Hegel 1977: 98). This is as true of Hegel's own intentions as it is of anyone else's.

I also wonder about the standards of 'accuracy' Brooks has in mind here. Is a reading of Hegel 'accurate' if it presents as cogently as possible what Hegel argued? If so, I think we 'non-systematic' readers are 'non-systematic' precisely because we are successfully striving for accuracy in this sense. Or should an 'accurate' interpretation ignore what is true 
in Hegel's theories and arguments, and present only Hegel's own account of what he intended to argue, whether not his actual arguments and insights correspond to his stated intention? Or is it both necessary and sufficient for 'accuracy' that the interpreter accept piously Hegel's assurances about what he both intended and accomplished, so that no gap between them is allowed even to be possible? If this last is what Brooks means by 'accuracy', then it does not seem an ideal worth aspiring to. For it would require a gross self-deception.

What would a 'systematic' reading of the Philosophy of Right be like, anyway? And does Brooks's own reading live up to its declared intentions in this regard?

The Philosophy of Right itself forms a system - the development of the idea of right $(P R \ 1)$ - and forms a determinate part of the system of philosophy (PR $\left.\int 2\right)$. The starting point of this development is the concept of freedom (PR $\int 4$ ), and its stages are 'abstract right', 'morality' and 'ethical life' (along with their internal divisions). By this standard, I submit that my book Hegel's Ethical Thought is quite a bit more 'systematic' that Brooks' own, since the Parts of my book correspond exactly to Hegel's systematic divisions. In that book, I also occasionally discuss Hegel's use of logical categories, when it seems to provide a genuine motivation for his views. I discuss these even more often in my editorial notes to the Nisbet translation of the Philosophy of Right, where they shed light on particular details of the text. It would be simply false to say that I ignore the role of Hegel's system or his speculative logic in the structure and argument of the Philosophy of Right, and although I do not want to undertake to defend other commentators whom Brooks characterises as 'non-systematic,' I think the same could be said of most of them as well. It is plainly invalid to infer from the fact that a commentator's says he does not think that Hegel's logic provides the sole key to understanding Hegel's argument to the conclusion that that commentator ignores the role of Hegel's logic or system.

Again, what would a 'systematic' reading be, anyway? One might think that 'systematic' reading of the Philosophy of Right must give first priority to identifying and explaining the way Hegel makes use in this work of various thought-determinations from his logic and the dialectical transitions from one to another. At first glance, Hegel's use of materials from his logical system might seem to be, if not arbitrary, at least opportunistic, and not themselves systematic at all. But there could be more to it, which a 'systematic' reading of the text ought to uncover, if there is to be any value to such a reading. Why, for instance, does Hegel systematise the three moments of 'possession,' and then the three moments of 'wrong,' using the positive, negative and infinite forms of judgment (PR \53, 88)? In Hegel's many uses of the three moments of the concept (universality, particularity, individuality) some of them proceed in the order just given (drawn from Kant's table of judgments) (e.g. PR \S 5-7, 119-129, 276-280, 282-285). But some of them (the three forms of possession, $\iint 56-58$, the three moments of morality $\int 114$, the three estates, $\int \mathbb{S} 302$, the three moments of the state constitution $\left.\int \$ 275-315\right)$ proceed in the opposite direction, from individuality toward universality. Why is this? What systematic explanation is there for the different order in the different cases? Or, to take 


\section{Allen Wood}

the largest possible question, what is the significance of the fact that right is systematised in a manner analogous to the system of logic as a whole —with Abstract Right corresponding to Being, Morality corresponding to Essence, and Ethical Life corresponding to the Concept, and the division of ethics likewise- family, civil society and the state (cf. PR \33)?

We look in vain in Brooks' monograph for any answers to questions like these. Brooks' 'systematic' reading of the Philosophy of Right has far too little to say, even for a 'non-systematic' reader like me, about Hegel's system of right. The eight chapters of Brooks' monograph, though they take matters up in the same order Hegel does, do not contain any systematic articulation of the divisions or the subdivisions within them. Instead, they discuss certain topics, such as punishment, monarchy and war, on which Hegel's views have interest for us today - thus embodying the very practices for which he criticises others for being 'non-systematic' and hence 'inaccurate'. Brooks's description of his own exegetical practice thus seems to be no more accurate than his description of the practice of others. In the event, his 'systematic' reading is no more systematic than the 'nonsystematic' readings he attacks. And where, on the ground of 'systematicity,' he cleaves to the letter of Hegel's doctrines, he often ends by confessing (exactly what he condemns us 'non-systematic' readers for saying) that there is little of lasting interest in them.

Thus Brooks does insist that Hegel's conception of monarchy depends on 'individuality' as a moment of the concept (Brooks 2007: 99-100), but he seems to admit that Hegel's rationale is unconvincing to modern readers, so he would appear to concede that there is little of philosophical interest in it. On the topic of war, Brooks also disavows any intention of 'rehabilitating' Hegel's views, taking no position on whether this can be done (p. 128). Regarding Hegel's treatment of the family, Brooks insists again that gender roles for Hegel are justified on the basis of speculative logic (Brooks 2007: 75). He then concludes his discussion by saying that 'nothing in this chapter is designed to make Hegel's views more appealing, ... but [with a systematic reading] we can make best sense of his arguments and improve on past accounts. The systematic reading is a better reading of Hegel's Philosophy of Right' (Brooks 2007: 80-81).

Here I have to wonder whether his standards for a 'better reading' are any more defensible than his standards for 'accuracy'. If we read Hegel 'systematically,' it appears that any attempt to find in Hegel anything about the family or monarchy from which we might still have something to learn would be off limits. We are stuck with Hegel's dated and wrongheaded views, supported by arguments drawn from his speculative logic that convince no one, least of all Brooks himself. The 'better reading', by Brooks' standard, seems to be one on which Hegel's views seem worthy only of the contemptuous dismissal they have received by many philosophers who would be ashamed to admit they have ever read any Hegel. Anyone who tries to correct the anti-Hegelian prejudices of

such readers is condemned by Brooks as 'non-systematic' and 'inaccurate'. It is hard to see the point of Brooks' 'systematic' reading if this is going to be its result.

\section{Bulletin of the Hegel Society of Great Britain}


So far, I have been taking Brooks at his word, and treating his book as if it did only what it professes to be doing. But it is now time to say, what I believe, that this badly sells his book short (just as his dismissal of mine and other 'non-systematic' books sells them short). When Brooks is willing to look away for a moment from his polemics against other scholars on behalf of his stated project of reading Hegel 'systematically, a lot of what he says in this book is interesting and illuminating, or at least worthy of discussion. He argues cogently, for instance, that Hegel's charge of 'emptiness' against Kantian ethics fails as applied to Kant, but that Hegel's quarry in this discussion is much broader than Kant's theory, and dependent on an understanding of 'morality' that is internal to and motivated by Hegel's 'unique understanding of what morality is and what moral theory can achieve' (Brooks 2007: 55-58). He also provides a rather creative interpretation of the issues between Kant and Hegel that brings in the role of religion (Brooks 2007: 58-60). He provides an illuminating discussion of the relation of Hegel's philosophy of law to the natural law tradition (Brooks 2007: 82-95). In his discussion of Hegel and war, he argues convincingly that Hegel does not advocate war (considering war as always something that ought not to be, and once it starts, something that ought to end), but does regard occasional wars as inevitable between independent states, and tries to understand the positive function war can have within the state (Brooks 2007: 114-128).

My search in his monograph for signs of a 'systematic' reading yielded mainly discussions in which Brooks insists that Hegel's full treatment of a given topic is not to be found in the principal passage in the Philosophy of Right where it is taken up, but requires us to consider other passages where the same topic is also discussed. Thus he insists that Hegel's full treatment of property is not exhausted by his discussion of it in Abstract Right, but requires consideration of his treatment of resources and estates in the sections on the family and civil society (Brooks 2007: 35-38). He likewise insists that Hegel's treatment of punishment must take into account not only what he says in the

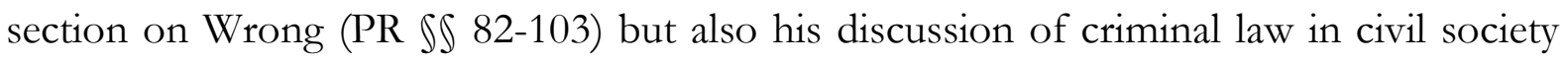
(\$S 218-229) (pp. 42-51). No doubt the later discussions in each case involve something about the structure of Hegel's system of right. But I do not see anything in Brooks' treatment that sheds special light on the systematic structure itself or makes use of it in defense of his interpretation. If there is no more to a 'systematic' reading of Hegel than a willingness to consider all the passages in which he discusses a given topic, then I don't think there is anything very distinctive to the 'systematic' reading, or even anything that separates it from us 'non-systematic' interpreters, since we can (and do) read the whole of a Hegel text just as easily as the 'systematic' readers can.

I also think, however, that Brooks' use of Hegel's different discussions of these topics has a tendency to mislead him. Contrary to what Brooks says, but perfectly in line with Hegel's systematic intentions, Hegel's fundamental defense of private property is to be found in his discussion of the immediate objectification of the will in Abstract Right, and his fundamental justification of punishment is solely the retributivist one he offers in the section on criminal wrong and justice (especially PR SS 97-101). The later discussions of 


\section{Allen Wood}

the concrete consequences of property rights under civil society shed light on the conditions under which these aspects of abstract right find their application in modern ethical life; but they do not, and are not intended to, replace or even supplement the fundamental rationale Hegel gives for private property or legal punishment, which is solely the one given under Abstract Right.

Something similar occurs in Brooks's treatment of Hegel's theory of punishment. The fact that punishment may be used for deterrence, and that its measure is given by historical conditions of civil society in a given time and place do not justify saying (as Brooks does) that Hegel's theory of punishment is 'only minimally retributive' and 'linked more closely with the threat to security in civil society' (Brooks 2007: 51). On the contrary, punishment for Hegel is in its concept retributive, though its further development in the context of civil society brings out some complexities not immediately present in the concept. This is very much in line with Hegel's view that the fundamental concept of a determination presents it in its immediacy, while its developed actuality contains features a merely immediate view might not have suspected. A more genuinely systematic reading of Hegel's theory of punishment would have resulted in an interpretation that was not only more accurate to his intentions, but also more defensible. I have had many occasions to regret the way I began Hegel's Ethical Thought, by insisting there is much to it that does not depend on the obscurities and sophistries of Hegel's speculative logic of thought-determinations. For this beginning only provoked the coterie of Hegel-devotees (who were bound to be among the first readers of such a book) to react with the same kinds of invalid inferences and gross misunderstandings I have already found in Brooks' criticism. It has been Hegel's unfortunate fate to attract many followers afflicted with a sad defect of character: They are stubbornly devoted, in defiance of all the world, to the proposition that Hegel's writings are the repository of some mysterious philosophical truth of which all non-Hegelians must forever remain in hopeless and contemptible ignorance. Each devotee's fanatical commitment to this article of faith is exceeded only by the commitment to the more private dogma that only $I$ (this particular fanatical Hegel-devotee) correctly understand what that truth really is. It was obviously a regrettable misstep on my part to tread on the sensitive toes of such people in the introduction to my book.

It is clearly too late to correct that now. It is also too late, I am sad to say, to offer Brooks analogous advice about the way he ought to have begun his book. This was perhaps the deplorable mirror-image of the way I began mine: for Brooks begins by pledging allegiance to Hegel's 'system' and denouncing as a 'non-systematic' heretic anyone who has the temerity to doubt whether Hegel's dialectic of thoughtdeterminations provides the sole and sufficient Rosetta Stone needed to reveal the meaning of his ethical and political thought. Once he gets off this hobby-horse, however, and begins actually discussing Hegel's ethics and political philosophy, his monograph is really pretty good. There is quite a bit to be learned about Hegel's moral and political 
philosophy from reading it. It is marred chiefly by two things: (1) his failure to ask and answer certain interpretive questions that arise precisely from Hegel's systematic intentions, and (2) his predictably tedious repetition of the slogan - like the little moral at the end of an Aesop's fable - that 'the systematic reading of the Philosophy of Right is the best one.'

\section{Allen Wood \\ Stanford University \\ allen.wood@stanford.edu}

\section{Bibliography}

Beiser, Frederick (2005) Hegel London: Routledge.

Brooks, Thom (2007) Hegel's Political Philosophy: A Systematic Reading of the Philosophy of Right Edinburgh: Edinburgh University Press

Hegel, G. W. F. (1970) Phänomenologie des Geistes. Werke: Theorie Werkausgabe. Bd.3. Frankfurt, Suhrkamp Verlag.

Hegel, G. W. F. (1977) Phenomenology of Spirit. Transl. A. V. Miller. Oxford: Oxford University Press.

Hegel, G. W. F. (1967) Philosophy of Right. Transl. T. M. Knox. Oxford: Clarendon Press. Wood, Allen (1990), Hegel's Ethical Thought New York: Cambridge University Press. 